\title{
Degradation and Mineralization of Malachite Green Dye in Aqueous Solution by Electro-Fenton Process Using Iron Electrodes
}

\author{
Maryam Teimouri, ${ }^{1}$ Hassan Khorsandi, ${ }^{1}$ Ali Ahmad Aghapour, ${ }^{1}$ and Seyed Javad Jafari ${ }^{1,}$ \\ ${ }^{1}$ Department of Environmental Health Engineering, School of Public Health, Urmia University of Medical Sciences, Urmia, Iran \\ "Corresponding author: Seyed Javad Jafari, Department of Environmental Health Engineering, School of Public Health, Urmia University of Medical Sciences, Urmia, Iran. Tel: \\ +98-4432752300, Fax: +98-4432770047, E-mail: sjavadj@gmail.com
}

Received 2018 May 23; Accepted 2018 June 03.

\begin{abstract}
The electrochemical degradation of a synthetic solution of malachite green (MG) was studied using electro-Fenton process (EFP) under batch conditions. The studies used iron electrodes to investigate the influence of operating parameters such as reaction temperature, distance between the electrodes, electrolysis time, and initial dye concentration. The values of $1 \mathrm{~cm}$ as distance between the electrodes and $50^{\circ} \mathrm{C}$ as temperature were found to be the optimum operating parameters for the efficient degradation of MG dye. When the temperature was greater than $50^{\circ} \mathrm{C}, \mathrm{H}_{2} \mathrm{O}_{2}$ self-decomposed. After 30 minutes of electrolysis, TOC removal was only $76.5 \%$ when no $\mathrm{H}_{2} \mathrm{O}_{2}$ was added to the solutions (ECP), while the presence of $\mathrm{H}_{2} \mathrm{O}_{2}$ greatly improved TOC removal by more than $95 \%$. For a solution of $1000 \mathrm{mg} \mathrm{L}^{-1} \mathrm{MG}$ dye, degradation was complete after only 30 minutes. Furthermore, despite high removal efficiency of COD in EFP, energy consumption was less than in ECP.
\end{abstract}

Keywords: Malachite, Electro-Fenton Process, Iron Electrodes

\section{Background}

In recent years, the use of organic dyes in many industries such as textile, cosmetics, plastics, food, and leather has increased considerably $(1,2)$. By estimation, the production of dyes is over $7 \times 10^{5}$ tons per year and $10 \%-15 \%$ of these dyes are given to aqueous environments $(1,3)$. These data show that the quality of water resource is strongly threatened since dyes not only give an unpleasant color to the waters but also, in some cases, can generate perilous by-products through reactions taking place in the waste phase $(4,5)$.

Malachite green (MG), a cationic triphenylmethane dye, is used as a biocide in the aquaculture industry (6, $7)$. This biocide is highly effective against important fungal and protozoal organisms (8); it is also used as a dye for materials such as cotton, silk, paper, leather, and ceramics $(6,7,9)$. MG is difficult to biodegrade and has toxic effects on human cells, experimental mammals and other aquatic animals (7). It may cause liver tumor, skin diseases, and even skin cancer after prolonged exposure $(10,11)$. Nevertheless, it is still used in many areas of the world due to its low cost, availability, and ready efficaciousness, and for lack of suitable alternatives $(6,7)$. Owing to its widespread use, MG can cause serious contamination to the environ- ment (7).

Several methods including ozonation, chemical oxidation, electrochemical oxidation, coagulation, adsorption, and nanofiltration are used in treatment of dye in wastewater $(7,9,12)$. Recently, advanced oxidation processes (AOPs) have been recommended as an efficient option for degradation of dye from wastewater (13). In these processes, the hydroxyl free radicals generated are responsible for the oxidation of organic pollutants (6). Among the AOPs, the Fenton process, which is based on an electron transfer between hydrogen peroxide $\left(\mathrm{H}_{2} \mathrm{O}_{2}\right)$ and a metal catalyst $\left(\mathrm{Fe}^{2+}\right)$, is the most commonly used due to its high efficiency and simplicity in operation $(6,14)$. In the Fenton process, hydroxyl free radicals $(\mathrm{OH})$ are produced in an acid mixture of $\mathrm{Fe}^{2+}$ and $\mathrm{H}_{2} \mathrm{O}_{2}$, according to the following Equation $((9,15)$ :

$\mathrm{Fe}^{2+}+\mathrm{H}_{2} \mathrm{O}_{2} \rightarrow \mathrm{Fe}^{3+}+\mathrm{OH}^{-}+\mathrm{OH}$

In recent years, several researchers have used advanced electrochemical oxidation processes (EAOPs) such as electro-Fenton process (EFP) to treat a variety of dyes (6). EFP can be divided into three classes depending on the purpose of current supply. The Fenton sludge recycling method uses electrical current to induce the reduction of ferric hydroxide sludge to form $\mathrm{Fe}^{2+}$. In the "EF- 
$\mathrm{H}_{2} \mathrm{O}_{2}$ " method, ferrous ion is added from the outside and hydrogen peroxide is generated using an oxygen spraying cathode. In the "EF-Fe ox" method, $\mathrm{H}_{2} \mathrm{O}_{2}$ is added from the outside while ferrous ion is produced by the oxidation of sacrificial iron anode. The last class is similar to the process used in this study $(14,16)$.

To date, the degradation of MG dye has been conducted in various EF systems using different electrode materials. Table 1 summarizes these studies in the selected published literature. Accordingly, EF reactors have been operated in low concentrations of MG dye in order to attain sufficient removal efficiency. Thus, the main aim of this work is to investigate the removal efficiency of EFP using sacrificial iron electrodes for degradation of a high concentration of MG dye. In this regard, the effect of reaction temperature, distance between the electrodes, electrolysis time, concentration of MG dye, kinetic of the reaction, COD removal, mineralization efficiency and energy consumption of EFP and ECP were determined. Some experimental parameters were already optimized $(\mathrm{pH}=3$, current density $=10 \mathrm{~mA}$ $\mathrm{Cm}^{-2}, \mathrm{CH}_{2} \mathrm{O}_{2}=50 \mathrm{mg} \mathrm{L}^{-1}$ ) and $94 \%$ color was removed under these optimum conditions for $200 \mathrm{mg} \mathrm{L}^{-1}$ of MG after only 10 minutes of treatment.

\section{Methods}

\subsection{Chemicals}

Malachite green, chemical formula $=\mathrm{C}_{23} \mathrm{H}_{25} \mathrm{ClN}_{2}, \lambda$ $\max =618 \mathrm{~nm}, \mathrm{MW}=364.911 \mathrm{~g} \mathrm{~mol}^{-1}$, was purchased from Aldrich. A stock solution ( $5 \mathrm{~g} \mathrm{~L}^{-1}$ ) of MG dye was prepared in distilled water and diluted when necessary. The chemicals used in this study $\left(\mathrm{H}_{2} \mathrm{SO}_{4}, \mathrm{NaOH}\right.$, and $\left.\mathrm{H}_{2} \mathrm{O}_{2}\right)$ were obtained from Merck company.

\subsection{Electrolytic System}

The electrochemical batch reactor was made of glass, 8 $\mathrm{cm}$ high and $5 \mathrm{~cm}$ in diameter, with a working volume of $250 \mathrm{~mL}$. Two iron plate electrodes (i.e., one anode and one cathode) with measuring $60 \times 40 \times 2 \mathrm{~mm}$ were located in reactor. The total active electrode surface area was $10 \mathrm{~cm}^{2}$. The cathode and anode sets were connected to negative and positive outlets of DC power supply (PS-305D model; $30 \mathrm{~V}, 5 \mathrm{~A}$ ) respectively, which discharged electrical current into the mixture when needed. Before each experiment, in order to remove organic impurities and oxide layer active electrode surface area, were soaked in $\mathrm{HCl}$ solution (30\%) for 5 minutes, and then rinsed with distilled water. In all experiments, a magnetic stirrer (Alfa, HS-860) was used (300 $\mathrm{rpm}$ ) to create turbulence completely and ensure homogenous condition in the reactor (Figure 1 ).

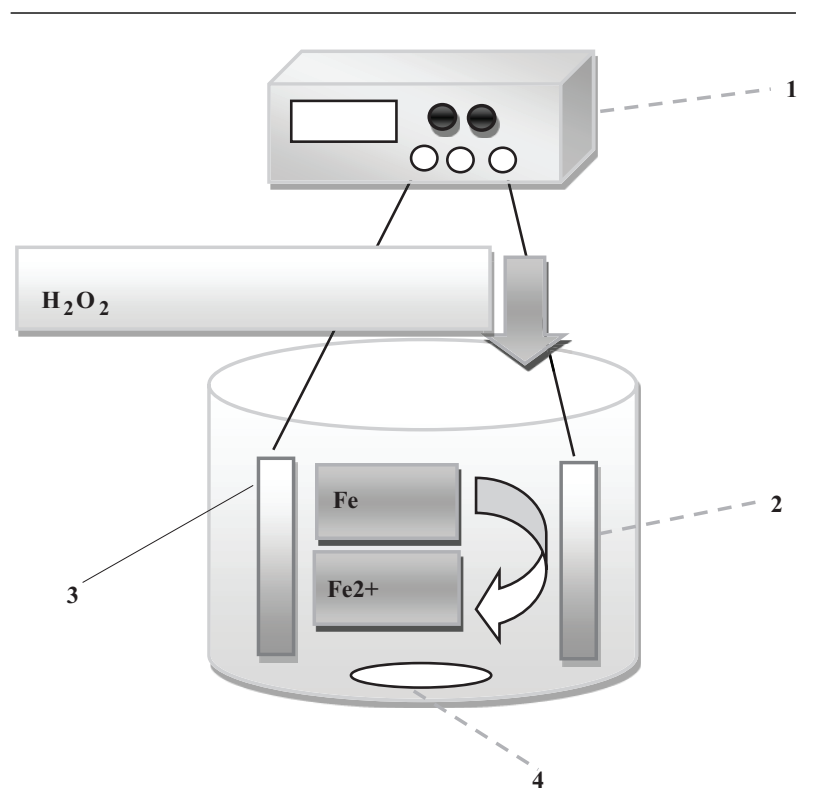

Figure 1. Experimental setup; power supply (1), sacrificial anode (2), cathode (3), magnetic stirrer (4)

\subsection{Analytical Procedures}

In each run, the initial $\mathrm{pH}$ of $250 \mathrm{~mL}$ of dye solution was adjusted to 3 (AZ 8651 model) using $1 \mathrm{~N} \mathrm{H}_{2} \mathrm{SO}_{4}$ or $1 \mathrm{~N} \mathrm{NaOH}$, and was then placed in the reactor. To increase conductivity, $500 \mathrm{mg} \mathrm{L}^{-1}$ of $\mathrm{NaCl}$ was used in all experiments as supporting electrolyte. Before turning on the power supply, a specific amount of $\mathrm{H}_{2} \mathrm{O}_{2}\left(\mathrm{mg} \mathrm{L}^{-1}\right)$ was added to electrochemical reactor to initiate the EF process. At the end of the process, $20 \mathrm{~mL}$ of reaction mixture was taken and centrifuged at $4000 \mathrm{rpm}$ for 5 minutes (Heraeus Labofuge 200 model). The centrifuged dye solution was then analyzed to determine the COD, TOC, and residual concentration of MG. COD measurements were performed using COD digestion vials, high range, (HACH Chemical) with a spectrophotometer(DR5000, HACH). The removal efficiency (Y) of dye solution was determined by measuring absorbance values before and after treatment process in the max wavelength $\left(\lambda_{\max }=619 \mathrm{~nm}\right)$ based on the following Equation:

$\% Y=\frac{A_{0}-A_{1}}{A_{0}} \times 100$

Where $A_{0}$ and $A_{1}$ are absorbance values before and after treatment process, respectively.

The limit of MG dye mineralization in EFP and ECP was measured by determining total organic carbon (TOC) of the solution using TOC analyzer (Shimadzu) before and after the processes. Percentage of TOC removal was calculated as follows: 


\begin{tabular}{|c|c|c|c|c|}
\hline Electrodes & Experimental Conditions & $\begin{array}{l}\text { Malachite Green Concentration, } \\
\qquad \mathrm{mg} \mathrm{L}^{-1}\end{array}$ & Removal Efficiency, \% & Reference \\
\hline Graphite felt-Pt & $\begin{array}{l}\left(\mathrm{Fe}^{3+}\right)=0.2 \mathrm{mM} \text {, electrolysis time }=22 \\
\text { min, applied current }=200 \mathrm{~mA} \\
\left(\mathrm{Na}_{2} \mathrm{SO}_{4}\right)=0.05 \mathrm{mM}, \mathrm{pH}=3 \text {, at room } \\
\text { temperature }\end{array}$ & 182.5 & 100 & (5) \\
\hline CF-BDD & $\begin{array}{l}\left(\mathrm{Fe}^{2+}\right)=0.5 \mathrm{mM} \text {, electrolysis time }=30 \\
\text { min, current density }=21.7 \mathrm{~mA} \mathrm{~cm}{ }^{-2} \\
\left(\mathrm{Na}_{2} \mathrm{SO}_{4}\right)=0.05 \mathrm{mM}, \mathrm{pH}=3, \\
\text { temperature }=25^{\circ} \mathrm{C}\end{array}$ & 150 & 86 & (6) \\
\hline Carbon PTFE-Pt sheet & $\begin{array}{l}\left(\mathrm{Fe}^{2+}\right)=0.5 \mathrm{mmol} \mathrm{dm}{ }^{-3}, \text { electrolysis } \\
\text { time }=15 \mathrm{~min}, \text { current density }=66.7 \\
\mathrm{~mA} \mathrm{~cm}^{-2}\left(\mathrm{Na}_{2} \mathrm{SO}_{4}\right)=0.05 \mathrm{~mol} \mathrm{dm}-3 \\
\mathrm{pH}=3, \text { temperature }=35^{\circ} \mathrm{C}\end{array}$ & 177 & 98 & (17) \\
\hline Carbon felt-Pt & $\begin{array}{l}\left(\mathrm{Fe}^{3+}\right)=0.2 \mathrm{mM} \text {, electrolysis time }= \\
12.5 \mathrm{~min} \text {, applied current }=60 \mathrm{~mA}, \\
\left(\mathrm{Na}_{2} \mathrm{SO}_{4}\right)=0.05 \mathrm{M}, \mathrm{pH}=3 \text {, at room } \\
\text { temperature }\end{array}$ & 18 & 100 & (18) \\
\hline $\begin{array}{l}\text { Carbon felt coated with iron } \\
\text { oxides-BDD }\end{array}$ & $\begin{array}{l}\left(\mathrm{Fe}^{2+}\right)=0.5 \mathrm{mM}, \text { electrolysis time }=15 \\
\text { min, current density }=21.7 \mathrm{~mA} \mathrm{~cm}{ }^{-2} \\
\left(\mathrm{Na}_{2} \mathrm{SO}_{4}\right)=0.05 \mathrm{M}, \mathrm{pH}=3, \\
\text { temperature }=25^{\circ} \mathrm{C}\end{array}$ & 150 & 74 & (19) \\
\hline $\begin{array}{l}\text { Cathode and anode, both made of } \\
\text { iron }\end{array}$ & $\begin{array}{l}\text { Solution } \mathrm{pH}=3 \text {, current density }=10 \\
\mathrm{~mA} \mathrm{~cm}{ }^{-2}, \mathrm{H}_{2} \mathrm{O}_{2} \text { dosage }=50 \mathrm{mg} \mathrm{L}^{-1} \text {, } \\
\text { reaction time }=30 \mathrm{~min}\end{array}$ & $1000-3000$ & $65-100$ & Present study \\
\hline
\end{tabular}

$\operatorname{TOC} \operatorname{removl}(\%)=\left(1-\frac{T O C_{t}}{T O C_{0}}\right) \times 100$

Where $\mathrm{TOC}_{\mathrm{t}}$ and $\mathrm{TOC}_{0}\left(\mathrm{mg} \mathrm{L}^{-1}\right)$ are the initial and final TOC of the solution, respectively (9).

Energy consumption is electrical spent to reduce per unit mass of COD, which was calculated using the following Equation:

$$
E C\left(K W h g^{-1} C O D\right)=\frac{V I t}{(\Delta C O D) V_{S}}
$$

Where $\mathrm{V}$ is average cell voltage in volte $(\mathrm{V})$, I is the applied current in ampere (A), $\mathrm{t}$ is the experiment time (hour), ( $\triangle \mathrm{COD}$ ) is the corresponding COD decay $\left(\mathrm{mg} \mathrm{L}^{-1}\right.$ ), and $V_{S}$ is the volume of solution (17).

\section{Results and Discussion}

\subsection{Effect of Temperature}

To investigate the effect of reaction temperature on the removal efficiency of MG dye, electrolysis was performed at different temperatures of $25^{\circ} \mathrm{C}, 50^{\circ} \mathrm{C}$, and $60^{\circ} \mathrm{C}$. Figure 2 shows the results of this work. The removal efficiency of MG dye increased from $94 \%$ to $99 \%$ as the temperature increased from $25^{\circ} \mathrm{C}$ to $50^{\circ} \mathrm{C}$. Increasing the temperature would increase the reaction rate between $\mathrm{H}_{2} \mathrm{O}_{2}$ and the catalyst, and therefore increase the rate of generating oxidizing species such as hydroxyl free radicals. Moreover, a higher temperature can provide more energy for the reactant molecules to dominate reaction activation energy $(9,18)$. The results also illustrated that the degradation efficiency decreased to $94.5 \%$ when the temperature increased to $60^{\circ} \mathrm{C}$. This phenomenon can be explained by the lower concentration of dissolved oxygen and the selfdecomposition of $\mathrm{H}_{2} \mathrm{O}_{2}$ to water and oxygen at higher temperatures $(15,19)$. To get a better understanding of the role of temperature in this reaction, the following Equation is is used:

$\mathrm{P}_{\mathrm{H}_{2} \mathrm{O}_{2}}$ cons $=\left(\mathrm{H}_{2} \mathrm{O}_{2}\right.$ cons $_{E F P}-\mathrm{H}_{2} \mathrm{O}_{2}$ constem $)$

Where $\mathrm{PH}_{2} \mathrm{O}_{2}$ cons, $\mathrm{H}_{2} \mathrm{O}_{2}$ cons EFP, and $\mathrm{H}_{2} \mathrm{O}_{2}$ cons tem are pure $\mathrm{H}_{2} \mathrm{O}_{2}$ consumed in EFP, total $\mathrm{H}_{2} \mathrm{O}_{2}$ consumed in EFP and $\mathrm{H}_{2} \mathrm{O}_{2}$ consumed if the temperature is used alone. The highest amount of $\mathrm{H}_{2} \mathrm{O}_{2}$ consumed, if the temperature is used alone, is at $60^{\circ} \mathrm{C}$ equal to $22.8 \mathrm{mg} \mathrm{L}^{-1}$ but maximum and minimum amount of pure $\mathrm{H}_{2} \mathrm{O}_{2}$ consumed are at $50^{\circ} \mathrm{C}$ and $60^{\circ} \mathrm{C}$, respectively (Figure 2). This result shows that at higher temperatures, $\mathrm{H}_{2} \mathrm{O}_{2}$ undergoes self-decomposition (Equation 6) (18).

$\mathrm{H}_{2} \mathrm{O}_{2} \rightarrow \mathrm{H}_{2} \mathrm{O}+\frac{1}{2} \mathrm{O}_{2}$

In a study by Hameed et al. (20) similar results were also observed. Hameed et al. (20) reported that MG removals percentage increased from 85.59 to $98.14 \%$ as the temperature increased from $30^{\circ} \mathrm{C}$ to $50^{\circ} \mathrm{C}$ during the first 


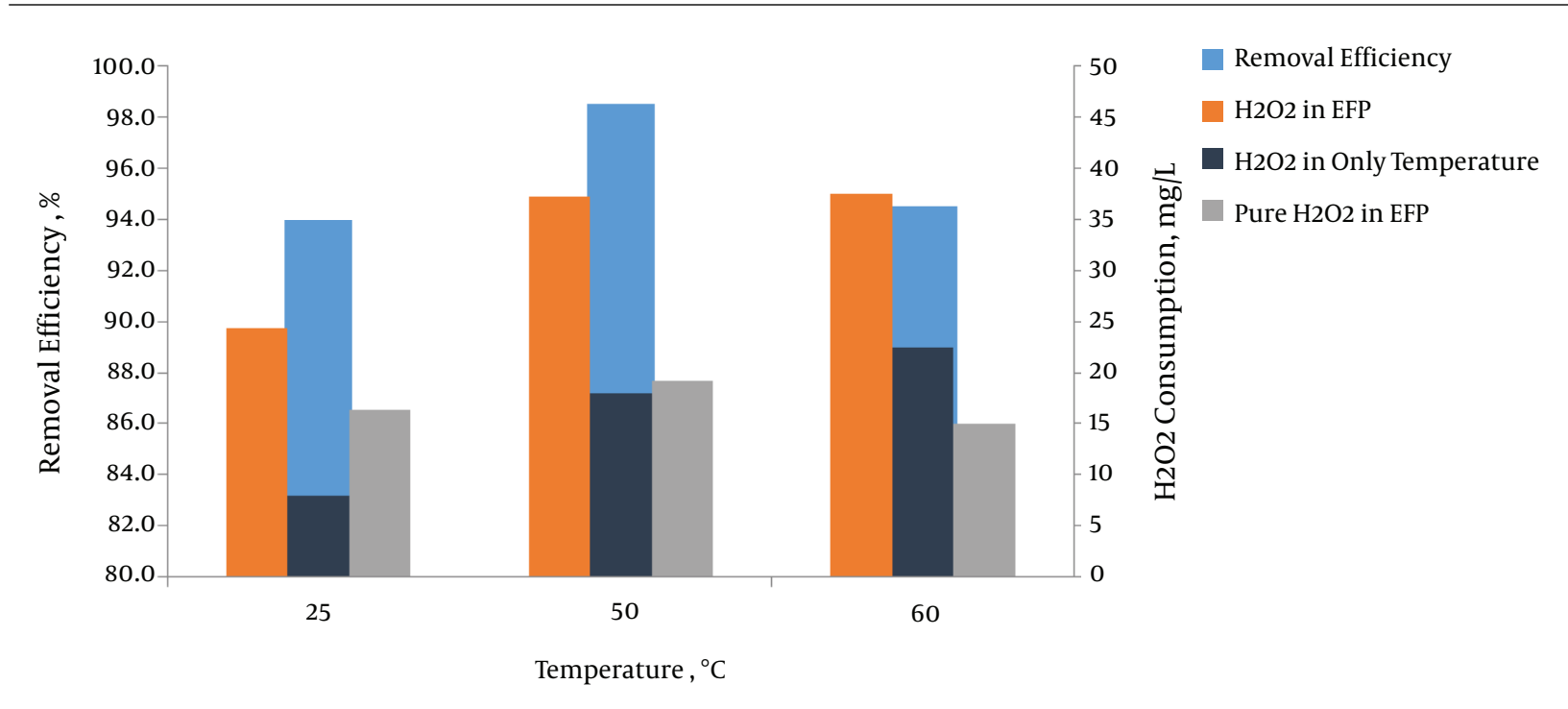

Figure 2. Degradation efficiency of MG dye at various temperature; Cdye $=200 \mathrm{mg} \mathrm{L}^{-1}, \mathrm{~T}=10$ minutes, $\mathrm{CD}=10 \mathrm{~mA} \mathrm{~cm}^{-2}, \mathrm{pH}^{2} 3, \mathrm{CH}_{2} \mathrm{O}_{2}=50 \mathrm{mg} \mathrm{L}^{-1}, \mathrm{~d}=1 \mathrm{~cm}$

10 minutes of the Fenton process. Panizza et al. (18) reported that the degradation rate of alizarin red dye increased when the temperature increased from $25^{\circ} \mathrm{C}$ to $35^{\circ} \mathrm{C}$.

\subsection{Distance Between the Electrodes}

To investigate the influence of space between the electrodes on treatment efficiency, the experiments were performed at varying electrode distance from 0.5 to $3 \mathrm{~cm}$. The results are presented in Figure 3. The MG removal percentages were observed to be $92.4 \%, 94,91.1 \%$, and $90.5 \%$ for electrode spacing of $0.5,1,2$, and $3 \mathrm{~cm}$, respectively. Accordingly, the maximum removal percentage was observed at $1 \mathrm{~cm}$ electrode spacing. By decreasing electrode spacing from 1 to $0.5 \mathrm{~cm}$, MG removal efficiency also decreased, because anodic oxidation of $\mathrm{Fe}^{2+}$ to $\mathrm{Fe}^{3+}$ could occur when the electrodes were placed too short (21). The removal efficiency decreased as the distance between the electrodes increased up to $1 \mathrm{~cm}$, because a longer distance between the electrodes can limit mass transfer of $\mathrm{Fe}^{3+}$ to the cathode surface which will govern $\mathrm{Fe}^{2+}$ regeneration (22). In addition, an increase in the space between the electrodes results in an increase in ohmic drop through the electrolyte and then an equivalent increase in cell voltage and energy consumption (23).

Our results agree with data achieved in other studies, such as COD and color removal from synthetic textile wastewater by EF method (24) and removal of salicylic acid from aqueous solution by EFP (21). Zang et al. (25) studied the removal of COD from landfill leachate by EFP and showed that there existed an optimal distance range between the electrodes $(1.3-2.1 \mathrm{~cm})$ so that an over $7 \%$ higher

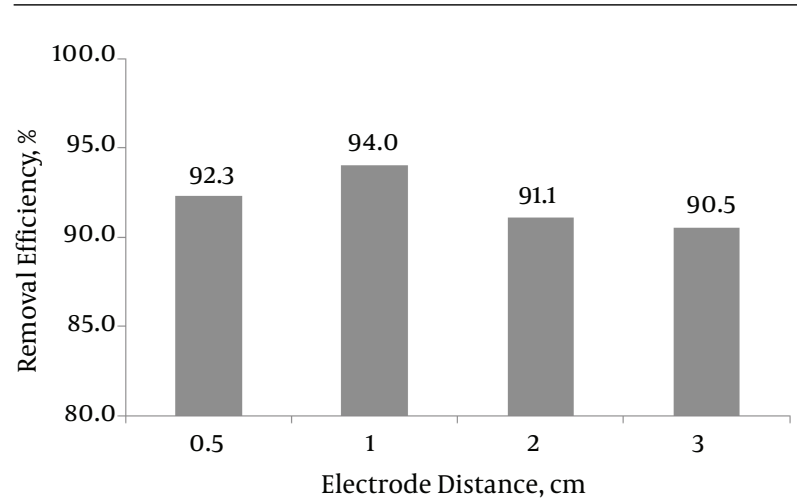

Figure 3. Effects of distance between the electrodes on color removal; $\mathrm{Cdye}=200 \mathrm{mg}$ $\mathrm{L}^{-1}, \mathrm{~T}=10$ minutes, $\mathrm{CD}=10 \mathrm{~mA} \mathrm{~cm}{ }^{-2}, \mathrm{pH}=3, \mathrm{CH}_{2} \mathrm{O}_{2}=50 \mathrm{mg} \mathrm{L}^{-1}$, temperature $=25^{\circ} \mathrm{C}$

COD removal was achieved than when the electrodes were positioned beyond this range. Thus, the distance of $1 \mathrm{~cm}$ was determined as optimum for the experiment.

\subsection{Mineralization Study}

Figure 4 illustrates the rate of dye mineralization as a function of electrolysis time in the EFP and ECP. EFP efficiency was obviously higher than that of ECP. After $30 \mathrm{~min}$ utes of treatment, more than $95 \%$ of TOC was removed in EFP, meaning that almost all the organic compounds were entirely mineralized to $\mathrm{CO}_{2}$ and $\mathrm{H}_{2} \mathrm{O}$ while the mineralization efficiency of ECP after 30 minutes was $76.5 \%$. As observed, EFP showed more mineralization efficiency over than ECP; the unselective attaches of hydroxyl free radi- 


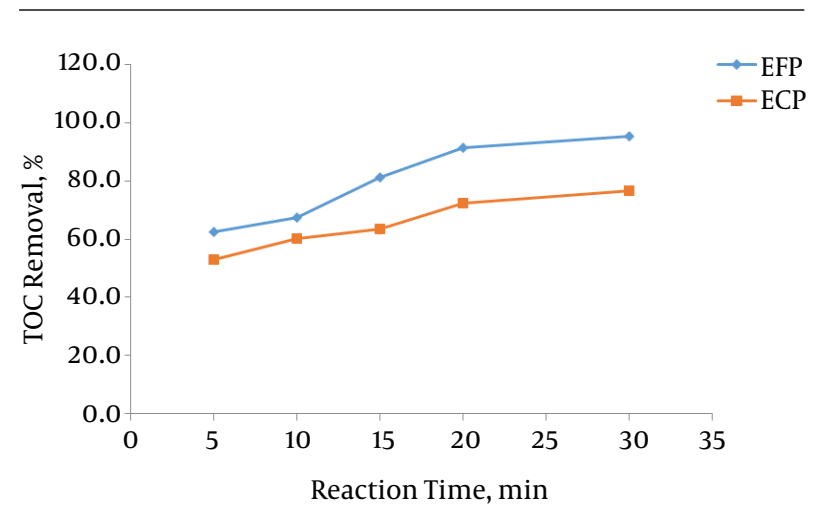

Figure 4. Time-coarse of MG mineralization by EFP and ECP; $\mathrm{CD}=10 \mathrm{~mA} \mathrm{~cm}{ }^{-2}, \mathrm{pH}=$ $3, \mathrm{CH}_{2} \mathrm{O}_{2}=50 \mathrm{mg} \mathrm{L}^{-1}, \mathrm{~d}=1 \mathrm{~cm}$, temperature $=25^{\circ} \mathrm{C}$

cals and EFP's high oxidation potential accounted for the higher mineralization power of $\operatorname{EFP}(26)$.

Akyol et al. (27) investigated removal efficiencies of the liquid organic fertilizer manufacturing wastewater by EFP and ECP using iron electrodes. In their study, EFP resulted in higher removal efficiencies ( $81 \%$ of TOC in $10 \mathrm{~min}$ ) than that of ECP (79\% of TOC in 45 minutes).

\subsection{Energy Consumption}

The energy consumption values in the EFP and ECP for mineralization of MG dye in different time intervals are calculated and presented in Table 2. Despite high removal efficiency of COD in EFP, the energy consumptions were less than in the ECP. For example, energy consumption in EFP was $0.0189 \mathrm{kWh} \mathrm{g}^{-1}$ COD after 30 minutes for $96.2 \%$ of COD reduction, while only $77 \%$ of COD abated consuming $0.0236 \mathrm{kWh} \mathrm{g}^{-1}$ COD in ECP.

\begin{tabular}{l|c|c|c}
\hline \multicolumn{3}{l}{$\begin{array}{l}\text { Table 2. Energy Consumption Values in the EFP and ECP. Initial COD of Sample }=304 \\
\mathrm{mg} \mathrm{L}^{-1}, \mathrm{CD}=10 \mathrm{~mA} \mathrm{~cm}^{-2}(\mathrm{I}=0.18 \mathrm{~A}), \mathrm{pH}=3, \mathrm{CH}_{2} \mathrm{O}_{2}=50 \mathrm{mg} \mathrm{L}^{-1}, \mathrm{~d}=1 \mathrm{~cm}, \mathrm{~V}=15.4(\mathrm{v})\end{array}$} \\
\hline \multirow{2}{*}{ Time, Min } & Kind of Process & $\begin{array}{c}\text { COD Removal, } \\
\%\end{array}$ & EC, $\mathbf{k W h} / \mathbf{g}$ COD \\
\hline \multirow{2}{*}{$\mathbf{5}$} & EF & 63.9 & 0.0047 \\
\cline { 2 - 4 } & EC & 55 & 0.0055 \\
\hline \multirow{2}{*}{$\mathbf{1 0}$} & EF & 72.9 & 0.0083 \\
\cline { 2 - 4 } & EC & 70.1 & 0.0086 \\
\cline { 2 - 4 } & EF & 85 & 0.0107 \\
\hline \multirow{2}{*}{$\mathbf{2 0}$} & EC & 72.2 & 0.0126 \\
\cline { 2 - 4 } & EF & 92.8 & 0.0131 \\
\hline \multirow{3}{*}{$\mathbf{3 0}$} & EC & 75.3 & 0.0161 \\
\hline
\end{tabular}

According to Hafaied et al. (17) energy consumptions were approximately $1 \mathrm{kWh} / \mathrm{g}$ COD when EFP was applied to treatment of Acid Red18 synthetic solution using a graphite-felt cathode (electrolysis time $=1$ hours, initial $\mathrm{COD}=56 \mathrm{mg} \mathrm{L}^{-1}$, COD removed $=30 \%, \mathrm{~V}=250 \mathrm{~mL}, \mathrm{I}=250$ $\mathrm{mA})$.

\subsection{Conclusion}

It has been demonstrated that a synthetic solution of MG dye at high concentrations can be effectively degraded by EFP using sacrificial iron electrode. Under optimal value of process parameters, $96.2 \%$ of COD removal was obtained after only 30 minutes of treatment. Under our experimental conditions, the total organic carbon measurements showed an efficient mineralization of $95.3 \%$ after 30 minutes of treatment. Moreover, it was found that despite high removal efficiency of COD in the EFP, energy consumption was lower than in ECP. Overall, EFP seems to be a clean and efficient method for the degradation of MG dye in wastewater.

\section{References}

1. Fernández C, Larrechi MS, Callao MP. An analytical overview of processes for removing organic dyes from wastewater effluents. $\operatorname{Tr} A C$ Trends Analyt Chem. 2010;29(10):1202-11. doi:10.1016/j.trac.2010.07.011.

2. Garg VK, Kumar R, Gupta R. Removal of malachite green dye from aqueous solution by adsorption using agro-industry waste: a case study of Prosopis cineraria. Dyes Pigm. 2004;62(1):1-10. doi: 10.1016/j.dyepig.2003.10.016.

3. Guenfoud F, Mokhtari M, Akrout H. Electrochemical degradation of malachite green with BDD electrodes: Effect of electrochemical parameters. Diam Relat Mater. 2014;46:8-14. doi: 10.1016/j.diamond.2014.04.003.

4. Ghoneim MM, El-Desoky HS, Zidan NM. Electro-Fenton oxidation of Sunset Yellow FCF azo-dye in aqueous solutions. Desalination. 2011;274(1-3):22-30. doi: 10.1016/j.desal.2011.01.062.

5. Oturan MA, Guivarch E, Oturan N, Sirés I. Oxidation pathways of malachite green by Fe3+-catalyzed electro-Fenton process. Appl Catal B. 2008;82(3-4):244-54. doi:10.1016/j.apcatb.2008.01.016.

6. Bañuelos JA, García-Rodríguez O, El-Ghenymy A, Rodríguez-Valadez FJ, Godínez LA, Brillas E. Advanced oxidation treatment of malachite green dye using a low cost carbon-felt air-diffusion cathode. J Environ Chem Eng. 2016;4(2):2066-75. doi:10.1016/j.jece.2016.03.012.

7. Singh S, Srivastava VC, Mall ID. Electrochemical treatment of malachite green dye solution using iron electrode. Int J ChemTech Res. 2013;5(2):592-6.

8. Srivastava S, Sinha R, Roy D. Toxicological effects of malachite green. Aquat Toxicol. 2004;66(3):319-29. doi: 10.1016/j.aquatox.2003.09.008. [PubMed: 15129773].

9. Hashemian S. Fenton-like oxidation of malachite green solutions: Kinetic and thermodynamic study. J Chem. 2013;2013:1-7. doi: $10.1155 / 2013 / 809318$.

10. Kousha M, Farhadian O, Dorafshan S, Mahboobi Soofiani N. [Investigation of the kinetics and nature of malachite green biosorption by green microalgae]. Water Wastewater. 2015;3:37-50. Persian.

11. Mirhasani A, Shahbazi A, Hasheminejad H, Sartaj M. [Optimization of the adsorption of malachite green on the $\mathrm{NH} 2-\mathrm{SBA}-15$ nano-adsorbant using the taguchi method by gualitic-4 software an isotherm, 
kinitic,and thermodynamic study]. Water Wastewater. 2014;25(6):109. Persian.

12. Man LW. Design of experiments for Malachite Green dye removal from wastewater using thermolysis-coagulation-flocculation. Desalination Water Treat. 2012;40(1-3):260-71.

13. Rosales E, Iglesias O, Pazos M, Sanroman MA. Decolourisation of dyes under electro-Fenton process using Fe alginate gel beads. $J$ Hazard Mater. 2012;213-214:369-77. doi: 10.1016/j.jhazmat.2012.02.005. [PubMed: 22381372].

14. Babuponnusami A, Muthukumar K. Advanced oxidation of phenol: A comparison between Fenton, electro-Fenton, sono-electro-Fenton and photo-electro-Fenton processes. Chem Eng J. 2012;183:1-9. doi: 10.1016/j.cej.2011.12.010.

15. Wang CT, Chou WL, Chung MH, Kuo YM. COD removal from real dyeing wastewater by electro-Fenton technology using an activated carbon fiber cathode. Desalination. 2010;253(1-3):129-34. doi: 10.1016/j.desal.2009.11.020.

16. Anotai J, Lu MC, Chewpreecha P. Kinetics of aniline degradation by Fenton and electro-Fenton processes. Water Res. 2006;40(9):1841-7. doi: 10.1016/j.watres.2006.02.033. [PubMed: 16624370].

17. Hafaiedh NB, Bellakhal N. Mineralization of synthetic and industrial food effluent containing acid red 18 by electro-fenton process using a graphite-felt cathode. Int J Sci Res. 2013;6(14).

18. Panizza M, Cerisola G. Electro-Fenton degradation of synthetic dyes. Water Res. 2009;43(2):339-44. doi: 10.1016/j.watres.2008.10.028. [PubMed: 18996554].

19. Wang CT, Hu JL, Chou WL, Kuo YM. Removal of color from real dyeing wastewater by Electro-Fenton technology using a threedimensional graphite cathode.J Hazard Mater. 2008;152(2):601-6. doi: 10.1016/j.jhazmat.2007.07.023. [PubMed: 17707581].
20. Hameed BH, Lee TW. Degradation of malachite green in aqueous solution by Fenton process. J Hazard Mater. 2009;164(2-3):468-72. doi: 10.1016/j.jhazmat.2008.08.018. [PubMed: 18804913].

21. George SJ, Gandhimathi R, Nidheesh PV, Ramesh ST. Electro-fenton oxidation of salicylic acid from aqueous solution: Batch studies and degradation pathway. Clean (Weinh). 2014;42(12):1701-11. doi: 10.1002/clen.201300453.

22. Qiang Z, Chang JH, Huang CP. Electrochemical regeneration of Fe2+ in Fenton oxidation processes. Water Res. 2003;37(6):1308-19. doi: 10.1016/S0043-1354(02)00461-X. [PubMed: 12598195].

23. Nidheesh PV, Gandhimathi R. Trends in electro-Fenton process for water and wastewater treatment: An overview. Desalination. 2012;299:115. doi: 10.1016/j.desal.2012.05.011.

24. Şahinkaya S. COD and color removal from synthetic textile wastewater by ultrasound assisted electro-Fenton oxidation process. Ind Eng Chem Res. 2013;19(2):601-5. doi:10.1016/j.jiec.2012.09.023.

25. Zhang H, Zhang D, Zhou J. Removal of COD from landfill leachate by electro-Fenton method. J Hazard Mater. 2006;135(1-3):106-11. doi: 10.1016/j.jhazmat.2005.11.025. [PubMed: 16359785].

26. Farhadi S, Aminzadeh B, Torabian A, Khatibikamal V, Alizadeh Fard M. Comparison of COD removal from pharmaceutical wastewater by electrocoagulation, photoelectrocoagulation, peroxielectrocoagulation and peroxi-photoelectrocoagulation processes. $J$ Hazard Mater. 2012;219-220:35-42. doi: 10.1016/j.jhazmat.2012.03.013. [PubMed: 22464981].

27. Akyol A, Can OT, Demirbas E, Kobya M. A comparative study of electrocoagulation and electro-Fenton for treatment of wastewater from liquid organic fertilizer plant. Sep Purif Technol. 2013;112:11-9. doi: 10.1016/j.seppur.2013.03.036. 